\title{
DIALEKTOMETRI SEGITIGA: HUBUNGAN KEKERABATAN BAHASA DI SULAWESI TENGGARA (BAHASA WAKATOBI, BAHASA CIA-CIA, BAHASA PANCANA, BAHASA KIOKO, BAHASA TOLAKI)
}

\author{
TRIANGULAR DIALEKTOMETRY: \\ THE RELATIONSHIP OF THE FAMILY OF LANGUAGE IN SOUTH \\ SULAWESI \\ (WAKATOBI LANGUAGE, CIA-CIA LANGUAGE, PANCANA \\ LANGUAGE, KIOKO LANGUAGE, TOLAKI LANGUAGE)
}

\author{
Susiati \\ susiatiuniqbu@gmail.com
}

\begin{abstract}
Abstrak
Keunikan bahasa setiap daerah menunjukkan identitas daerah tertentu, sehingga penting untuk dilakukan suatu kajian yang dapat dengan jelas menunjukkan keunikan tersebut. Penelitian ini bertujuan mendeskripsikan fenomena penggunaan bahasa pada beberapa bahasa daerah di Sulawesi Tenggara dengan menerapkan analisis dialektometri segitiga. Instrumen penelitian ini menggunakan pendekatan dialektometri. Metode pengumpulan data yang dipakai pada penelitian ini adalah metode pupuan lapangan (metode lapangan langsung). Data penelitian ini dianalisis dengan menggunakan metode dialektometri segitiga. Metode ini memakai angka-angka sebagai dasar pemilahannya. Hasil penelitian menunjukan bahwa keseluruhan titik pengamatan yang di analisis menggunakan dialektometri, masuk pada kategori empat formulasi, yaitu formulasi di bawah 20\% (tidak ada perbedaan bahasa dan dialek, yakni antara bahasa Wakatobi dialek Kaledupa dan dialek Tomia), formulasi 31-50 \% (adanya perbedaan subdilek, yaitu antara bahasa Pancana dan bahasa Kioko), formulasi 51-80\% (perbedaan dialek, yakni antara bahasa Wakatobi dialek Tomia dan bahasa Pancana; bahasa Pancana dan bahasa Wakatobi dialek Kaledupa; bahasa Kioko dan bahasa Wakatobi dialek Tomia; bahasa Wakatobi dialek Tomia dan bahasa Cia-Cia; bahasa Cia-Cia dan bahasa Kioko; bahasa Kioko dan bahasa Tolaki), dan formulasi 81 ke atas (perbedaan bahasa, yakni antara bahasa Tolaki dan bahasa Cia-Cia).
\end{abstract}

Kata kunci: hubungan kekerabatan, dialektometri segitiga, bahasa, sulawesi tenggara

\begin{abstract}
The uniqueness of each region's language signifies the identity of a particular region, so it is important to do a study that can clearly show the uniqueness. This study aims to describe the phenomenon of language usage in several languages in Southeast Sulawesi by applying a triangular dialectometry analysis. The instrument of this research using dialectometry approach. Data collection methods used in this study is a method of field fucking (direct field method). Data of this research were analyzed by using triangle dialectomentry method. This method uses the numbers as a basis for sorting. The results showed that the overall observation point in the analysis using dialectometry, entered in the four formulation categories, namely the formulation below 20\% (no language and dialect differences, ie between the Wakatobi language Kaledupa dialect and Tomia dialect), formulation 31-50\% (the difference subdilek, that is between Pancana Language and Kioko Language), formulation 51-80\% (dialect difference, ie between the Wakatobi language Tomia dialect and Pancana languages; Pancana language and Wakatobi
\end{abstract}


language Kaledupa dialect; Kioko Language and Wakatobi language Tomia dialect; Wakatobi language Tomia dialect and Cia-Cia; Cia-Cia Language and Kioko Language; Kioko Language and Tolaki Language), and formulations 81 and above (language differences, between Tolaki and Cia-Cia languages).

Keywords: language, relationship of the family, triangular dialectometry, south sulawesi

\section{Pendahuluan}

Bahasa merupakan sesuatu yang sangat vital dalam kehidupan manusia. Apalagi dalam kehidupan tersebut adanya proses interaksi yang menyambungkan antara manusia yang satu dengan manusia yang lain. Dalam proses interaksi sosial pelakunya selalu menggunakan alat, yakni bahasa dalam menyampaikan ide, gagasan, harapan, dan sebagainya. Suatu daerah mempunyai bahasa pertama atau bahasa ibu yang masih dominan digunakan sebagai pengantar komunikasi antarmasyarakat.

Di negara Indonesia ini, terdapat banyak etnis yang tersebar dari Sabang sampai Marauke. Setiap kelompok etnis memiliki bahasa dan dialek sendiri. Bahasa dan dialek tersebut digunakan untuk berkomunikasi antar sesama masyarakat dalam etnik tersebut. Selain itu, mereka juga memiliki budaya dan latar belakang sosial yang berbeda dengan beragam jenis vernacular. Oleh karena itu, berbagai bahasa dan budaya tersebut harus dipertahankan untuk menjaga keberagaman dalam persatuan sebagai warisan negara Indonesia (Wacana, 2013).

Terihat pula di Provinsi Sulawesi Tenggara yang memiliki banyak daerah yang tiap daerah tersebut mempunyai bahasa daerah masing-masing sehingga menimbulkan pertanyaan "apakah bahasa daerah pada tiap daerah di Provinsi Sulawesi Tenggara tersebut memiliki perbedaan atau terdapat persamaan kosakata?". Jawaban untuk pertanyaan seperti ini adalah dengan dilakukannya suatu pemetaan bahasa-bahasa daerah yang ada di Provinsi Sulawesi Tenggara. Hubungan bahasa-bahasa sekerabat ternyata tidak sama dekat antara satu bahasa dengan yang lain, ada yang lebih dekat dan jauhnya disebut dengan subgrouping (Blust, 1977).

Bahasa-bahasa yang ada di Sulawesi merupakan bahasa yang tergolong dalam rumpun bahasa Austronesia. Blust (1977) menegaskan pula bahwa kelompok Melayu Polynesia yang merupakan turunan dari bahasa Austronesia terdiri dari dua kelompok, yaitu kelompok Melayu Polynesia Barat dan kelompok Melayu Polynesia Tengah/Timur. Kelompok Melayu Polynesia Barat menurunkan bahasa di Philipina, Malaysia, Vietnam, Malagasi, Indonesia bagian barat (Sumatera, Jawa, Kalimantan, Sulawesi, Bali, Lombok, dan Sumbawa bagian barat) sedangkan Indonesia bagian tengah/timur menurunkan bahasa-bahasa di pulau Sumba, Flores, Timor, Maluku Tengah, dan selatan.

Ihwal pemetaan bahasa-bahasa daerah di Indonesia sebenarnya sudah cukup lama dan banyak dilakukan, tidak lama setelah Indonesia merdeka, Teeuw (1951) sarjana berkebangsaan Belanda, memulai proyek pemetaan bahasa daerah di Indonesia dengan mengambil objek bahasa Sasak di Lombok.

Sepanjang kurun waktu pengembangan pemetaan pada pertengahan 1980-an, pusat pembinaan dan pengembangan bahasa telah banyak melakukan analisis dialektologis terhadap berbagai bahasa daerah di Indonesia. Bahasa-bahasa daerah yang ada di Indonesia memiliki ciri dan karakteristik yang berbeda antara satu bahasa dengan bahasa yang lain. Keunikan bahasa setiap daerah menandakan identitas daerah tertentu, sehingga penting untuk dilakukan suatu kajian yang dapat dengan jelas menunjukkan keunikan tersebut.

Hal itu perlu menjadi perhatian utama, karena kebanyakan dalam menyebut bahasa yang satu dengan yang lain merupakan bahasa yang berbeda atau hanya perbedaan variasi, belumlah jelas. Masing-masing daerah tidak ingin bahasanya disamakan dengan bahasa di daerah yang lain.

Dewasa ini, penentuan apakah dua bahasa di daerah tertentu merupakan bahasa yang 
berbeda atau hanya satu bahasa dengan dua variasi yang berbeda, yang bisa jadi hanya perbedaan dialek masih terus dilakukan, tidak terkecuali pada beberapa bahasa yang ada di Sulawesi Tenggara.

Di Sulawesi Tenggara banyak bahasa daerah yang tersebar di beberapa lokasi. Keseluruhan bahasa daerah di Sulawesi Tenggara memiliki kekhasan yang berbedabeda. Oleh karena itu, peneliti mencoba menelaah beberapa bahasa tersebut dengan menggunakan perhitungan dialektometri untuk melihat seberapa besar tingkat variasi bahasabahasa tersebut. Dasar pemikiran ini bertolak dari hasil penelitian pemetaan bahasa oleh Esser (1938) yang membagi bahasa di Sulawesi Tenggara menjadi tujuh kelompok salah satunya adalah kelompok Muna-Buton yang anggotanya terdiri dari Muna-Buton, Buton Selatan, Wolio, Layolo, dan Wakatobi. Pengelompokkan bahasa di Sulawesi Tenggara pernah pula diteliti oleh Marafad (2001) yang mengelompokkan bahasa di Sulawesi Tenggara terdiri dari dua kelompok. Kelompok pertama, yaitu Bungku-Tolaki yang beranggotakan bahasa Wawonii, Kulisusu, Moronene, dan Tolaki. Kelompok kedua, yaitu Muna-Buton yang beranggotakan Busoa, Kambowa, Muna, Wolio, Cia-Cia, dan Wakatobi.

Bahasa-bahasa yang menjadi kajian dalam penelitian adalah bahasa Wakatobi dialek Kaledupa dan dialek Tomia, bahasa Kioko, bahasa Cia-Cia, bahasa Pancana, dan bahasa Tolaki.

Bahasa Wakatobi merupakan bahasa yang digunakan oleh penduduk asli Wakatobi. Bahasa tersebut merupakan bahasa pertama atau bahasa ibu. Kedudukan bahasa Wakatobi sangat penting dalam kehidupan masyarakat Wakatobi karena dominan masyarakatnya masih kental menggunakan bahasa ibu. Penggunaan bahasa Wakatobi selalu dijumpai penggunaannya dalam ranah keluarga, lingkungan masyarakat, maupun lingkungan kerja (sekolah dan kantor).

Bahasa Tolaki adalah salah satu bahasa yang dipertuturkan di daerah pegunungan Mekongga, Sulawesi Tenggara, Indonesia. Bahasa Tolaki memiliki dua tingkatan penggunaan bahasa, yaitu untuk orang yang dipertuakan dan orang yang seusia atau sederajat.

Bahasa Cia-Cia atau bahasa Buton Selatan, ialah jenis bahasa Austronesia yang wilayah pertuturannya di sekitar Kota Baubau dan di selatan Pulau Buton yang terletak di tenggara Pulau Sulawesi. Pada tahun 2009, bahasa ini menarik perhatian dunia ketika Kota Baubau menerima tulisan Hangul Korea untuk dijadikan sistem tulisan bahasa Cia-Cia. Pada tahun 2005 ada 80.000 orang penutur bahasa Cia-Cia, 95\% di antaranya beragama Islam yang juga berbicara dalam bahasa Wolio.

Penelitian ini bertujuan mendeskripsikan fenomena penggunaan bahasa pada beberapa bahasa di Sulawesi Tenggara dengan menerapkan analisis dialektometri segitiga. Pemetaan dengan dialektometri segitiga menentukan jumlah bahasa atau dialek dengan mengamati tingkat persentase perbedaan antara satu titik pengamatan dengan titik pengamatan yang lain.

Istilah dialektologi berasal dari kata dialect dan kata logi. Kata dialect berasal dari bahasa Yunani dialektos. Kata dialektos digunakan untuk menunjuk pada keadaan bahasa di Yunani yang memperlihatkan perbedaan-perbedaan kecil dalam bahasa yang mereka gunakan. Adapun kata logi berasal dari bahasa Yunani logos yang berarti 'ilmu'. Gabungan dari kedua kata ini berserta artinya membawa pengertian dialektologi sebagai ilmu yang memepelajari suatu dialek dari suatu bahasa dan dapat pula mempelajari dialekdialek yang ada dalam suatu bahasa.

Berdasarkan kelompok pemakaiannya, dialek dapat dibagi atas tiga jenis, yakni: (1) dialek regional, yaitu variasi bahasa berdasarkan perbedaan lokal (tempat) dalam suatu wilayah bahasa; (2) dialek sosial, yaitu variasi bahasa yang digunakan oleh golonga tertentu; dan (3) dialek temporal, yaitu variasi bahasa yang digunakan oleh kelompok bahasawan yang hidup pada waktu tertentu. Pendapat yang lazim tentang dialek sebagaimana dikemukakan dengan pemahaman yang dianut dalam rangkaian pembicaraan dialektologi, menurut pandangan dialektologi, semua dialek dari suatu bahasa mempunyai kedudukan yang sederajat, statusnya sama, 
tidak ada dialek yang lebuh berprestise dan tidak berprestise. Tidak ada juga sebutan bahwa dialek yang digunakan itu kampungan, meskipun penuturnya berasal dari desa. Semua dialek dari sebuah bahasa itu sama. Dialekdialek tersebut menjadikan fungsinya masingmasing dalam kelompok-kelompok masyarakat penuturnya. Dialek standar juga merupakan dialek bahasa, sama dengan dialek lainnya. Hanya karena faktor ekstralinguistik, dialek ini dianggap sebagai dialek yang berprestise (Fernandez, 1993).

Di samping istilah dialek, dikenal pula istilah isolek, idiolek, dan aksen. Istilah isolek merupakan istilah netral yang dapat digunakan untuk menunjuk pada bahasa, dialek, atau subdialek. Yang dimaksud dengan idiolek adalah ciri khas berbahasa seseorang karena setiap orang memiliki ciri khas dalam bertutur. Selanjutnya, istilah aksen digunakan untuk menunjuk pada cara penutur mengucapkan bunyi bahasa.

Dialektologi merupakan cabang linguistik yang mempelajari variasi bahasa. Variasi bahasa adalah perbedaan-perbedaan bentuk yang terdapat dalam suatu bahasa. Perbedaanperbedaan tersebut mencakup semua unsur kebahasaan, yaitu fonologi, morfologi, leksikon, sintaksis, dan semantik.

Dalam bidang fonologi, perbedaan tersebut dapat berupa perbedaan bunyi (lafal) dan dapat pula berupa perbedaan fonem. Dalam bidang morfologi perbedaan tersebut dapat berupa afiks (prefiks, infiks, sufiks, dan konfiks), pronominal, atau kata penunjuk. Dalam bidang sintaksis, perbedaan itu berupa struktur kalimat atau struktur frasa. Dan dalam bidang semantik, perbedaan itu berupa makna, tetapi makna tersebut masih berhubungan atau masih mempunyai pertalian, makna yang digunakan pada titik pengamatan tertentu dengan makna yang digunakan pada titik pengamatan yang lainnya masih berhubungan.

Pembeda dialek terdiri dari lima macam perbedaan sebagai berikut.

a. Perbedaan fonetik, yakni perbedaan yang berada di bidang fonologi dan biasanya pemakai dialek/bahasa yang bersangkutan tidak menyadari adanya perbedaan tersebut. b. Perbedaan semantik, yaitu terciptanya kata-kata baru berdasarkan perubahan fonologi dan geseran bentuk.

c. Perbedaan onomasiologis, yakni menunjukkan nama yang berbeda berdasarkan satu konsep yang diberikan dibeberapa tempat yang berbeda.

d. Perbedaan semasiologis, yaitu pemberian nama yang sama untuk beberapa konsep yang berbeda.

e. Perbedaan morfologis, yakni terciptanya inovasi bahasa.

Secara umum dialek dapat digolongkan menjadi 3 kelompok, yaitu:

a. Dialek 1, yaitu dialek yang berbeda-beda karena keadaan alam sekitar tempat dialek tersebut dipergunakan sepanjang perkembangannya (Warnant,1973).

Dialek ini dihasilkan karena adanya dua faktor yang saling melengkapi, yaitu faktor waktu dan faktor tempat.

b. Dialek 2, yakni bahasa yang dipergunakan di luar daerah pemakaiannya. Dialek ini sering juga disebut sebagai dialek regional atau enclave.

c. Dialek Sosial ialah ragam bahasa yang dipergunakan oleh kelompok tertentu, yang dengan demikian membedakannya dengan kelompok masyarakat lainnya (Kridalaksana, 2008). Ragam dialek sosial yang memperlihatkan ciri-ciri yang sangat khusus dikenal dengan nama argot atau slang.

\section{Metode}

\subsection{Instrumen Penelitian}

Instrumen merupakan perangkat bantu dalam memberikan dan membandingkan leksikon tiap bahasa daerah yang ada di Sulawesi Tenggara, dengan menggunakan pendekatan dialektometri. Instrumen Pendekatan ini bertujuan untuk mengukur secara statistik perbedaan aspek-aspek bahasa yang terdapat antara titik-titik pengamatan berdekatan dan membandingkannya dengan sejumlah bahan yang diperoleh dari daerah yang diteliti (Ayatrohaldi 1985; Nothofer 1980).

Pengolahan data dialektometri adalah membuat segitiga dialektometri, yaitu menghubungkan sebuah desa dengan desa 
terdekat dengan sebuah garis lurus. Setiap desa yang memiliki hubungan jarak terdekat akan dihitung jarak kosakatanya berdasarkan persentase perbedaan arti kata, baik untuk setiap kategori maupun untuk seluruh kata. Penghitungan perbedaan arti kata dilakukan dengan memanfaatkan logika matematika IF dalam program Ms Excel. Logika ini membandingkan arti kata dari kata yang sama pada dua lokasi (desa) yang berbeda. Hasil logika ini akan menampilkan bilangan biner, yaitu, menampilkan nilai 0 (nol) jika sama arti katanya atau nilai 1 (satu) jika beda arti katanya. Jumlah (SUM) dari seluruh nilai beda dibagi dengan jumlah seluruh kata yang dibandingkan dikalikan 100. Ini akan menghasilkan persentase perbedaan arti kata yang dibandingkan. Persentase perbedaan inilah yang menjadi jarak kosakata antardesa yang dibandingkan. Sementara itu, jarak lurus antardesa yang dibandingkan dihitung berdasarkan koordinat posisi kedua desa tersebut (Yatim dan Machmoed, 2007).

\subsection{Metode Pengumpulan Data}

Metode pengumpulan data yang dipakai pada penelitian ini adalah metode pupuan lapangan (metode lapangan langsung). Kata-kata yang diperoleh adalah hasil wawancara informan dengan berpatokan pada 200 kata Morris Swadesh yang diterjemankan ke tiap-tiap bahasa yang dianalsis. Hasil dari pengumpulan tersebut selanjutnya dijadikan sebagai data penelitian.

\subsection{Metode Analisis Data}

Data penelitian ini dianalisis dengan menggunakan metode dialektomentri segitiga. Metode ini memakai angka-angka sebagai dasar pemilahannya. Proses pemilahan dilakukan dengan menggunakan rumus yang diajukan Seguy-Guiter (dalam Lauder 2001) yaitu:

$$
\frac{s}{n} \times 100 \%=d
$$

$\mathrm{s}=$ jumlah beda dengan titik pengamatan lain

$\mathrm{n}=$ jumlah peta yang diperbandingkan

$\mathrm{d}=$ jarak kosa kata dalam \%
Dari hasil pemilahan bahasa-bahasa daerah tersebut selanjutnya, diformulasikan ke dalam empat formulasi, yakni formulasi di bawah $20 \%$ (tidak ada perbedaan bahasa dan dialek), formulasi $31-50 \%$ (adanya perbedaan subdialek), formulasi $51-80 \%$ (perbedaan dialek), dan formulasi $81 \mathrm{ke}$ atas (perbedaan bahasa).

\section{Hasil dan Pembahasan}

Berdasarkan hasil penelitian, dengan menghitung jumlah beda pemakaian kosa ata di satu daerah pengamatan lainnya yang dikalikan 100 lalu dibagi dengan jumlah nyata banyaknya peta yang dibandingkan diperoleh persentase jarak kosakata di antara kedua titik pengamatan itu.

Menurut Guiter (1973), jika penghitungan menghasilkan persentase :

$81 \%$ ke atas : dianggap perbedaan bahasa

$51 \%-80 \%$ : dianggap perbedaan dialek

$31 \%-50 \%$ : dianggap perbedaan subdialek

$21 \%$ - $30 \%$ : dianggap perbedaan wicara

Dibawah $20 \%$ : dianggap tidak ada perbedaan.

Berdasarkan ketentuan tersebut, didapatkan peta dasar segitiga dialektometri dari kelima kabupaten, yaitu :

1. Kabupaten Wakatobi (dialek Kaleduadialek Tomia)

2. Kabupaten Buton Selatan (bahasa Cia-Cia)

3. Kabupaten Buton Tengah (bahasa Pancana)

4. Kabupaten Buton Utara (Kioko)

5. Kabupaten Konawe Utara dan Konawe Selatan (bahasa Tolaki)

Dengan rincian dialek dan bahasa sebagai berikut:

1. Bahasa Wakatobi dialek Kaledupa

2. Bahasa Wakatobi dialek Tomia

3. Bahasa Cia-Cia

4. Bahasa Pancana

5. Bahasa Kioko

6. Bahasa Tolaki

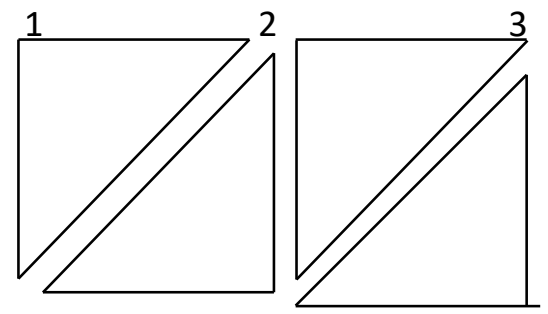


Berdasarkan segitiga dialektometri di atas, diperoleh titik-titik daerah penelitian sebagai berikut: (1) Segitiga 12 4; (2) Segitiga 24 5; (3) Segitiga 23 5; dan (4) Segitiga 536.

Di bawah ini akan dipaparkan distribusi leksikon:

1) Berdasarkan distribusi segitiga 124 , diperoleh titik perbandingan sebagai berikut:
a) 1:2 (bahasa Wakatobi dialek Kaledupa : bahasa Wakatobi dialek Tomia)
b) 2:4 (bahasa Wakatobi dialek Tomia : bahasa Pancana)
c) 4:1 (bahasa Pancana : bahasa Wakatobi dialek Kaledupa).

2) Berdasarkan distribusi segitiga 245 , diperoleh tiga perbandingan sebagai berikut:
b) 4:5 (bahasa Pancana : bahasa Kioko)
c) 5:2 (bahasa Kioko : bahasa Wakatobi dialek Tomia)

3) Berdasarkan distribusi segitiga 235 , diperoleh titik perbandingan sebagai berikut:
a) 2:3 (bahasa Wakatobi dialek Tomia : bahasa Cia-Cia)
b) 3:5 (bahasa Cia-Cia : bahasa Kioko)
c) 5:2 (bahasa Kioko : bahasa Wakatobi dialek Tomia)

4) Berdasarkan distribusi segitiga 536 , diperoleh titik perbandingan sebagai berikut:
a) 5:3 (bahasa Kioko : bahasa Cia-Cia)
b) 3:6 (bahasa Cia-Cia : bahasa Tolaki)
c) 6:5 (bahasa Tolaki : bahasa Kioko)

Berikut ini tabel pemetaan leksikon dari tiap daerah di Sulawesi Tenggara, yakni bahasa Wakatobi dialek Kaledupa dan dialek Tomia, bahasa Tolaki, bahasa Pancana, bahasa Kioko, dan bahasa Cia-Cia.

Tabel 1

Linguistik Bandingan Bahasa-Bahasa di Sulawesi Tenggara

\begin{tabular}{|c|l|l|l|l|l|l|l|}
\hline No & \multicolumn{1}{|c|}{ Gloss } & $\begin{array}{c}\text { Bahasa } \\
\text { Wakatobi } \\
\text { Dialek } \\
\text { Kaledupa } \\
\text { I }\end{array}$ & $\begin{array}{c}\text { Bahasa } \\
\text { Wakatobi } \\
\text { Dialek Tomia }\end{array}$ & \multicolumn{1}{c|}{$\begin{array}{c}\text { Bahasa } \\
\text { Cia-Cia }\end{array}$} & \multicolumn{1}{|c|}{$\begin{array}{c}\text { Bahasa } \\
\text { Pancana }\end{array}$} & $\begin{array}{c}\text { Bahasa } \\
\text { Kioko }\end{array}$ & \multicolumn{1}{c|}{$\begin{array}{c}\text { Bahasa } \\
\text { Tolaki }\end{array}$} \\
\hline 1 & abu & afu & gopo & awu & katowo & Abu & awu \\
\hline 2 & air & te'e & te;e & e'e & oe & Oe & iwoe \\
\hline 3 & akar & akka & akka & purasa & pahaka & Kahaa & haka \\
\hline 4 & aku & iyaku & yaku & inda'u & inodi & Inoi & inaku \\
\hline 5 & $\begin{array}{l}\text { alir } \\
\text { (meng) }\end{array}$ & fulu & fulu & wa'a & jala & $\begin{array}{l}\text { Nomengal } \\
\text { ir }\end{array}$ & tetewa \\
\hline 6 & anak & ana & ana & ungkaka & ana'i & Kaindai & ana \\
\hline 7 & angin & fande & fande & ngoi & kawea & Kawae & opua \\
\hline 8 & anjing & obu & obu & au & da'u & mantoa & o'dau \\
\hline 9 & apa & paira & tehira & para'e & yoae & fae & o'hawo \\
\hline 10 & api & ahu & lukapi & api & ifi & wea & api \\
\hline 11 & apung & lonto & lonto & ampe & lanto & nolanto & lulondo \\
\hline 12 & asap & ko'o & mbolo & hau & gawu & umbo & ahu \\
\hline 13 & awan & lono & lono & olu & olu & yooulu & awu \\
\hline 14 & $\begin{array}{l}\text { bagaiman } \\
\text { a }\end{array}$ & afanaumpa & afanaumpa & ma'impa'e & ingka amai & ingkafae & te'embe \\
\hline 15 & baik & leama & ndeu & omela & polalo & metaa & meambo \\
\hline
\end{tabular}




\begin{tabular}{|c|c|c|c|c|c|c|c|}
\hline 16 & bakar & rampu/sula & sula & sula & tunu & cunu & hunu \\
\hline 17 & balik & kotti & kotti & bancule & wolita & paele & pebulili \\
\hline 18 & banyak & koruo & koruo & to'aru & bahi & nobahi & dadio \\
\hline 19 & bapak & ama & ama & ama & ama & ama & ama \\
\hline 20 & baring & mbale/nggolo & mbale/ndolo & pindondole & ndole & $\begin{array}{l}\text { kando- } \\
\text { kandole }\end{array}$ & moturu \\
\hline 21 & baru & fo'ou & foou & tam & bo'ou & wo'ou & wuohu \\
\hline 22 & basah & mepa & jepe & mbere & behe & bao & mosele \\
\hline 23 & batu & fatu & fatu & wacu & kontu & wacu & watu \\
\hline 24 & berapa & popia & asahira & popia & se'ae & sefaae & opio \\
\hline 25 & $\begin{array}{l}\text { belah } \\
\text { (mem) }\end{array}$ & fengka & folla & bongka & weta & towe & bela \\
\hline 26 & benar & kobe & kobe & kocuhu & nentoo & kocu'u & tekono \\
\hline 27 & benih & ponembula & pembula & wine & wine & wine & bibi \\
\hline 28 & bengkak & bangka & bangka & tente & gende & sudu & kamba \\
\hline 29 & berenang & $\begin{array}{l}\text { nangu- } \\
\text { nangu/loo }\end{array}$ & nangu-nangu & pikanangu & leni & lengi & lumango \\
\hline 30 & berjalan & fila & fila & hangka & dhala & ndala & lumulako \\
\hline 31 & berat & $\begin{array}{l}\text { mobohalmopo } \\
\text { ro }\end{array}$ & $\begin{array}{l}\text { mobohalmopo } \\
\text { ro }\end{array}$ & mboa & biye & biye & momeni \\
\hline 32 & beri & hu'u & hu'u & dawu & wa'ane & wa'ao & powei \\
\hline 33 & besar & to'oge & tooha & to'owa & bala & no'oge & owose \\
\hline 34 & bilamana & ibara & ibara & $\begin{array}{l}\text { mbahaeno } \\
\text { mo }\end{array}$ & ungoko'omu & ibara & beteembe \\
\hline 35 & bisul & faho & faho & kabisu & kabisu & kabisu & pepiho \\
\hline 36 & bisa & kapoi & kapoi & mbali & nembali & nembali & tule \\
\hline 37 & buah & bake & bake & wua & wua & bake & wua \\
\hline 38 & bulan & komba & komba & wula & wula & wula & wula \\
\hline 39 & bulu & fulu & fulu & wulu & wulu & wulu & wulu \\
\hline 40 & bunga & kamba & kamba & kamba & kambea & kambea & bunga \\
\hline 41 & bunuh & hokomate & hokomate & pongko & pongko & fakamate & popate \\
\hline 42 & buta & kandala & kandala & mura & kabunto & kabunto & pedole \\
\hline 43 & buruk & da'o & dao & ndaki & kadaiwulu & nohingka & mosa'a \\
\hline 44 & burung & kadadi & kadadi & kadadi & $\begin{array}{l}\text { kamanu- } \\
\text { manu }\end{array}$ & $\begin{array}{l}\text { kadole- } \\
\text { kadole }\end{array}$ & $\begin{array}{l}\text { manu- } \\
\text { manu }\end{array}$ \\
\hline 45 & busuk & antida'o & peere & mbuto & buhu & buhu & tewuho \\
\hline 46 & cacing & undulati & undulati & hendeleci & undeletu & ndelecu & lodo-lodo \\
\hline 47 & cium & bobo & fobo & bobo & wono & bhobo & meuma \\
\hline 48 & cuci & honoha & honoha & wanui & tofa & tofa & mobusu \\
\hline 49 & daging & ramo/dagi & ramo & dagi & dagi & dagi & dagi \\
\hline 50 & dan & kene & kene & me & $\mathrm{ba}$ & lalo & ronga \\
\hline 51 & danau & tefeu & tefeu & dannau & umele & umele & danau \\
\hline 52 & darah & raha & raha & rea & hea & hea & beli \\
\hline 53 & datang & rato/mai & rato/mai & bundo & hato & hato & leu \\
\hline
\end{tabular}




\begin{tabular}{|c|c|c|c|c|c|c|c|}
\hline 54 & debu & afu & afu & hawu & bungahasi & buhangasi & owu \\
\hline 55 & daun & ro'o & roo & ro'o & hoo & hoo & tawa \\
\hline 56 & dekat & medani & medani & tatangku & koma'o & kamo'o & merambi \\
\hline 57 & dengan & kene & kene & mai & bae & bae & ranga \\
\hline 58 & dengar & ndongo & hikidongo & pindongo & fetingke & hendene & podea \\
\hline 59 & di dalam & di laro & ilalo & i lalo & wae lalo & wae lalo & lune \\
\hline 60 & di & $\mathrm{di}$ & $\mathrm{di}$ & $\overline{\mathrm{i}}$ & wae & wae & $\mathrm{i}$ \\
\hline 61 & di mana & di umpa & i maupa & i mpa'e & na'a mai & nde & inehawo \\
\hline 62 & dingin & kengku & kengku & dindi & hindi & mohindi & morini \\
\hline 63 & diri (ber) & karama/tade & karama/tade & tade & ehe & tade & $\begin{array}{l}\text { menggok } \\
\text { oro }\end{array}$ \\
\hline 64 & di sini & di ana & imiana & i kaina & nai'inini & ndeini & ikeni \\
\hline 65 & di situ & di iso & imiiso & i kaincu & nae maetu & nde icu & ikiro \\
\hline 66 & dorong & soro & soro & tola & dudulane & soho & soroi \\
\hline 67 & dua & dua & dua & dorua & dua & hudua & oru'a \\
\hline 68 & duduk & kede & kede & hora & ngkoha & mengkoha & $\begin{array}{l}\text { mendotor } \\
\mathrm{o}\end{array}$ \\
\hline 69 & ekor & iku & iku & ka'isu & lensi & lensi & ekor \\
\hline 70 & empat & ganna & pa'a & popa'a & paa & wopaa & o'omba \\
\hline 71 & engkau & iko'o & iko'o & iso'o & ihintu & incucu & inggoo \\
\hline 72 & gali & keke & keke & pongali & seli & seli & lombai \\
\hline 73 & garam & gara & gara & gara & gaha & gaha & peanihi \\
\hline 74 & garuk & kaho & hau & kosai & gehu & gehu & karui \\
\hline 75 & gemuk & mo'ofu & monufu & to'owa & kabala buku & mohumbu & mewalo \\
\hline 76 & gigi & koni & koni & ngi'i & wangka & limpo & ngisi \\
\hline 77 & gigit & kaha & kaha & kerepu & siapi & kukuci & kekeai \\
\hline 78 & gosok & kisi & koki & goso'e & dengo & pagisi & gosoi \\
\hline 79 & gunung & fungka/gunnu & fungka & kinamo & gunu & gunu & osu \\
\hline 80 & hantam & busuki/fandu & busuki/fandu & tandapa & wandu & bhebe & wanggui \\
\hline 81 & hapus & kisi & kisi & happusu'e & pusuli & hapususe & kukuhii \\
\hline 82 & hati & ate & ate & hate & ate & ate & ate \\
\hline 83 & hidung & bobo & ngo'o & ngo'o & nee & nee & ngusu \\
\hline 84 & hidup & membali & tumbu & dadi & uhi & moihi & tora \\
\hline 85 & hijau & ijo & ijo & ngkuri & kaijo & kaijo & maido \\
\hline 86 & hisap & ponno & ponno & sosopi & sosopi & gomi & mooso \\
\hline 87 & hitam & biru & biru & ngkito & kaito & kaito & meeto \\
\hline 88 & hitung & gana & reke & gagari & fiapi & ise & modoa \\
\hline 89 & hujan & monda & monda & kia & use & ise & usa \\
\hline 90 & hutan & kotu'a & kotua & $\begin{array}{l}\text { buntou/kan } \\
\text { cuka }\end{array}$ & kahumbu & kaampo & hutan \\
\hline 91 & ia & oho & oho & ia & umbe & umbe & oho \\
\hline 92 & ibu & ina & ina & ina & ina & ina & ina \\
\hline 93 & ikan & kenta & kenta & isa & kenta & kenta & owete \\
\hline
\end{tabular}




\begin{tabular}{|c|c|c|c|c|c|c|c|}
\hline 94 & ikat & boke & boke & boke & boke & bokee & onggo \\
\hline 95 & istri & bela & baisa & $\begin{array}{l}\text { mancuana } \\
\text { mwine }\end{array}$ & hobine & $\begin{array}{l}\text { sabangka } \\
\mathrm{ku}\end{array}$ & omore \\
\hline 96 & ini & ana & nae & nake’e & aini & ini & ino \\
\hline 97 & itu & atu & isoe & cuke'e & aitu & itu & inggito \\
\hline 98 & jahit & sangki & sangki & deu & sohomba & sohumba & moseu \\
\hline 99 & jalan & fila & fila & hangka & kangka'a & ndala & ocala \\
\hline 100 & jantung & bake & bake & kakara & sawu & ate & jantung \\
\hline 101 & jatuh & butti/tonnabu & monabu & ndawu & ndawu & mondawu & moisa \\
\hline 102 & jauh & mellai & mellai & mbelai & kodo'o & kodo'o & meilo \\
\hline 103 & kabut & gopo & luha & huburo & gawu & mogawu & gawu \\
\hline 104 & kaki & $\mathrm{ae}$ & ae & kake & a'e & a'e & o'kare \\
\hline 105 & kalau & ara & ara & ane & $\begin{array}{l}\text { ane amande } \\
\text { ane }\end{array}$ & $\begin{array}{l}\text { ane } \\
\text { naembali }\end{array}$ & kikua \\
\hline 106 & kami. kita & ikami / ikita & ikami & isami & insodi & insami & inggami \\
\hline 107 & kamu & iko'o & iko'o & iso'o & ihinto & incucu & inggo'o \\
\hline 108 & kanan & moana & moana & soana & suana & kema & hana \\
\hline 109 & kantung & kadu & kadu & kanto & kakadu & kakadu & kanto \\
\hline 110 & kata (ber) & pogau & bitara/pogau & pogau & pogau & pogau & teeni \\
\hline 111 & kecil & bahili & bahuli & kokodi & kau'ubu & kakidi & mohewu \\
\hline 112 & $\begin{array}{l}\text { kelahi } \\
\text { (ber) }\end{array}$ & $\begin{array}{l}\text { pobusu/pofand } \\
\mathrm{u}\end{array}$ & pafandu & pogira & powandu & pobusu & megaga \\
\hline 113 & kepala & kapala & kapala & pocu & wotu & focu & ulu \\
\hline 114 & kering & kakki & kakki & nginci & kekele & mokele & mowato \\
\hline 115 & kiri & mohii & moihi & sombali & kema & suana & suwa \\
\hline 116 & kotor & rakki & kotoro & kotoro & kita & kotoro & mokosisi \\
\hline 117 & kuku & kuku & kuku & kunusu & konisi & koninsi & koku \\
\hline 118 & kulit & kuli & kuli & sili & kuli & kuli & koli \\
\hline 119 & kuning & makuri & makuri & ngriri & kakuni & kakuni & mouso \\
\hline 120 & kutu & kutu & kutu & cucu & youutu & $\mathrm{du}$ & kutu \\
\hline 121 & lain & sagiu & sagiu & aga'anno & suano & segaino & mbonuho \\
\hline 122 & langit & langi & langi & olu & lani & olu & lahuene \\
\hline 123 & laut & mafi & tai & tai & te'i & te'i & tahi \\
\hline 124 & lebar & merofi & merofi & nlewa & ka'ewa & kolewe & melewe \\
\hline 125 & leher & kafu'u & fu'u & gonco & wu'u & wu'u & woroko \\
\hline 126 & lelaki & mo'ane & moane & mohane & moane & moane & langgai \\
\hline 127 & lempar & meta & meta & polola & pando & cumbe & rodo \\
\hline 128 & licin & molullungu & lila & ndolu & ndeli & mondeli & moloro \\
\hline 129 & lidah & ella & ella & ela & lela & lela & elo \\
\hline 130 & lihat & ita & sii & ita & woha & ondoe & monggii \\
\hline 131 & lima & lima & lima & lolima & dima & lidima & o'limo \\
\hline 132 & ludah & ilu & elu & pontori & elu & yoelu & eni \\
\hline 133 & lurus & toto/melloda & toto & ronto & toto & lurusu & mondolo \\
\hline
\end{tabular}




\begin{tabular}{|c|c|c|c|c|c|c|c|}
\hline 134 & lutut & tu'u & tuu & ncu'u & tuu & $\mathrm{cu}$ & o'ulutu \\
\hline 135 & main & aka-aka & kolia & po'andea & kalalambu & kalalambu & $\begin{array}{l}\text { mepae- } \\
\text { pae }\end{array}$ \\
\hline 136 & makan & manga & manga & ma'aso & fomaa & uma & monggaa \\
\hline 137 & malam & utu & utu & morondo & hondo & hondo & owingi \\
\hline 138 & manis & meko & meko & momeko & meko & meko & mesiu \\
\hline 139 & matahari & oloo & olo'o & holeo & oleo & oleo & o'leo \\
\hline 140 & mati & mate & mate & mate & mate & mate & mate \\
\hline 141 & merah & meha & meha & ndea & kadea & kadea & momea \\
\hline 142 & mereka & ammai & ammai & mo'ia & andoa & andoa & ihiro \\
\hline 143 & minum & moro'u & moroou & poroku & foho'u & foho'u & moinu \\
\hline 144 & mulut & ngusu & ngusu & boba & woba & nunsu & paadu \\
\hline 145 & muntah & tokkumbo & tokkumbo & polonai & tongka & tolua & peua \\
\hline 146 & nama & ngaa & ngaa & ngea & nea & kona & tamo \\
\hline 147 & napas & mona'a & mona'a & sina'a & iinea & fainei & penao \\
\hline 148 & nyanyi & $\begin{array}{l}\text { hekadangki/ka } \\
\text { banti }\end{array}$ & $\begin{array}{l}\text { hekadangki/ka } \\
\text { banti }\end{array}$ & pilagu & kabanti & kabanti & mosusua \\
\hline 149 & orang & mia & kene/mia & mia & miye & mia & toono \\
\hline 150 & panas & mena & mena & mpana & sodo & sodo & mokula \\
\hline 151 & panjang & melangka & melangka & ko'ata & wanta & melangka & mendaa \\
\hline 152 & pasir & one & one & hone & bone & komea & one \\
\hline 153 & pegang & konta & konta & unta & intaha & keni & mepoindi \\
\hline 154 & pendek & pera & menara & kokoampu & u'ubu & moompu & oputu \\
\hline 155 & peras & pinse & pense & kusu'e & feo & feo & pioi \\
\hline 156 & $\begin{array}{l}\text { perempua } \\
\mathrm{n}\end{array}$ & fofine & fofine & mwine & hobine & hobine & omore \\
\hline 157 & perut & kompo & kompo & hawa & handa & handa & tia \\
\hline 158 & pikir & fikiri & fikiri & fekihi & fekihi & fekihi & pikiri \\
\hline 159 & pohon & hu'u & huu & sau & pu'uno sau & puuno & pu'u \\
\hline 160 & potong & pale & pale & cumpo & tumpo & cumpo & polei \\
\hline 161 & punggung & pangku & pangku & bobose & pundo & totobu'u & toruku \\
\hline 162 & pusar & puo & hue & pue & pu'e & pue & puhe \\
\hline 163 & putih & mohute & mohute & mpute & pute & mopute & mopute \\
\hline 164 & rambut & hotu & hotu & pocu & fotu & wu & wu'u \\
\hline 165 & rumput & hofo & hofo & ka'awo & woli & woli & rembu \\
\hline 167 & sayap & kappi & kappi & papani & pani & pani & oaso \\
\hline 168 & sedikit & bahili & bahuli & adeide & kaindadi & sekidi & pani \\
\hline 169 & siang & moina & moina & ntalea & mentae & melanta & sobita \\
\hline 170 & siapa & ye'e & yee & nde'ea & la'ae & lafae & menggaa \\
\hline 171 & sempit & masopi & masopi & ngimpi & iimpi & mogimpi & inae \\
\hline 172 & semua & ba'anne & baannoe & $\begin{array}{l}\text { sambambal } \\
\text { ie }\end{array}$ & bahindo & $\begin{array}{l}\text { kobahi- } \\
\text { bahie }\end{array}$ & mombipi \\
\hline 173 & suami & bela & baisa & $\begin{array}{l}\text { mancuana } \\
\text { mhane }\end{array}$ & moane & $\begin{array}{l}\text { sabangka } \\
\text { ku }\end{array}$ & luwuako \\
\hline
\end{tabular}




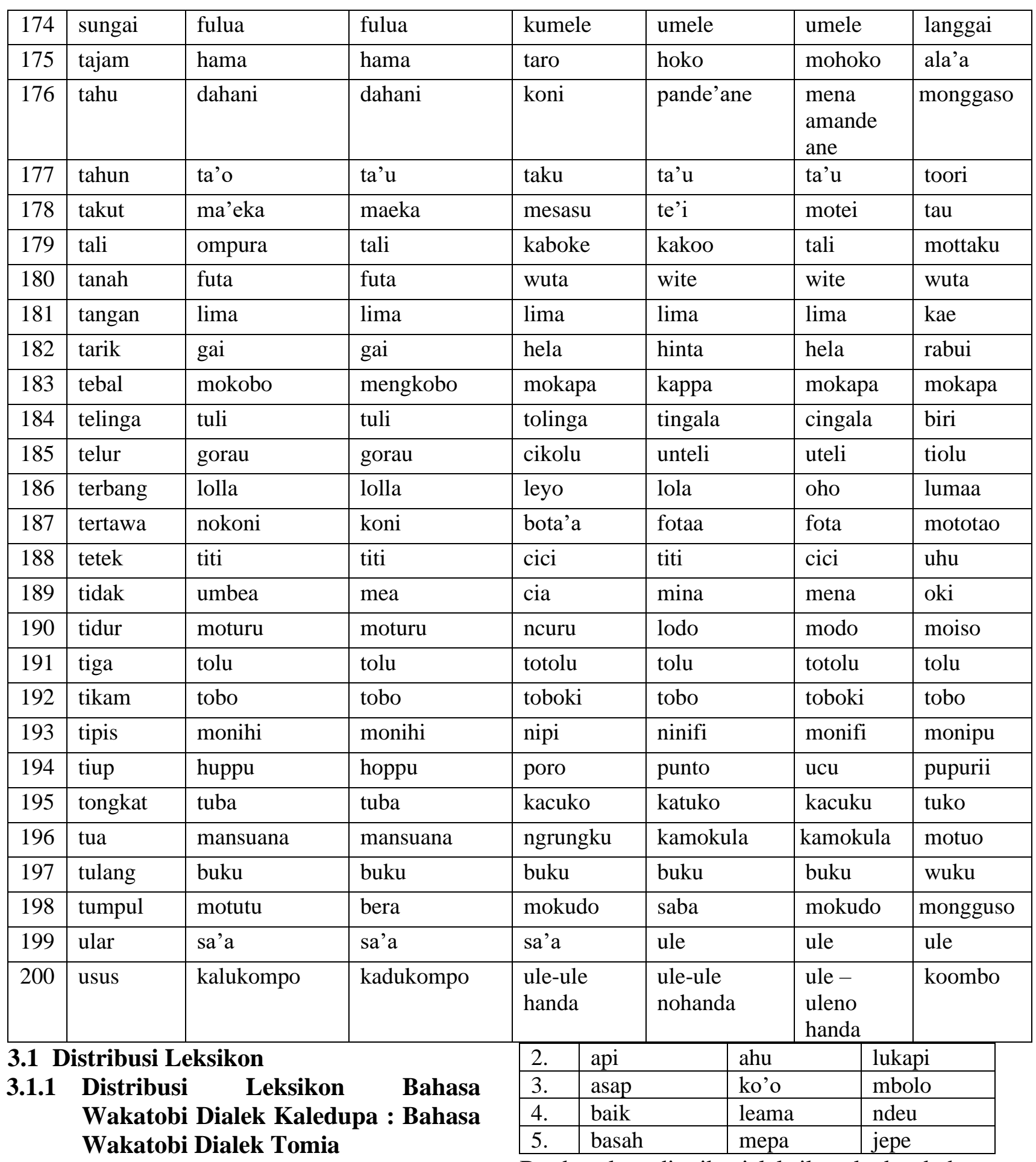

Di bawah ini akan disajikan sebagian contoh data leksikon yang berbeda antara bahasa Wakatobi dialek Kaledupa dengan bahasa Wakatobi dialek Tomia.

Tabel 2

Berdasarkan distribusi leksikon kedua bahasa di atas, terdapat 29 perbedaan leksikon yang tidak kognat.

\subsubsection{Distribusi Leksikon Bahasa Wakatobi Dialek Tomia : Bahasa Pancana}

Kaledupa dan Bahasa Wakatobi Dialek Tomia

\begin{tabular}{|l|l|l|l|}
\hline No. & Gloss & $\begin{array}{l}\text { Wakatobi } \\
\text { Dialek } \\
\text { Kaledupa }\end{array}$ & $\begin{array}{l}\text { Wakatobi } \\
\text { Dialek } \\
\text { Tomia }\end{array}$ \\
\hline 1. & abu & afu & gopo \\
\hline
\end{tabular}

Di bawah ini akan disajikan sebagian contoh data leksikon yang berbeda antara bahasa Wakatobi dialek Tomia dengan bahasa Pancana. 
Tabel 3

Data Leksikon Antara Bahasa Bahasa Wakatobi Dialek Tomia dan Bahasa Pancana

\begin{tabular}{|l|l|l|l|}
\hline No. & Gloss & $\begin{array}{l}\text { Bahasa } \\
\text { Wakatobi } \\
\text { Dialek } \\
\text { Tomia }\end{array}$ & $\begin{array}{l}\text { Bahasa } \\
\text { Pancana }\end{array}$ \\
\hline 1. & abu & gopo & katowo \\
\hline 2. & air & te;e & oe \\
\hline 3. & akar & akka & pahaka \\
\hline 4. & aku & yaku & inodi \\
\hline 5. & alir (meng) & fulu & jala \\
\hline
\end{tabular}

Berdasarkan distribusi leksikon kedua bahasa di atas, terdapat 144 perbedaan leksikon yang tidak kognat.

\subsubsection{Distribusi Leksikon Bahasa Pancana} : Bahasa Wakatobi Dialek Kaledupa

Di bawah ini akan disajikan sebagian contoh data leksikon yang berbeda antara bahasa Wakatobi dialek Kaledupa dengan bahasa Pancana.

Tabel 4

Data Leksikon Antara Bahasa Bahasa Wakatobi Dialek Kaledupa dan Bahasa Pancana

\begin{tabular}{|l|l|l|l|}
\hline No. & Gloss & $\begin{array}{l}\text { Bahasa } \\
\text { Wakatobi } \\
\text { Dialek } \\
\text { Kaledupa }\end{array}$ & $\begin{array}{l}\text { Bahasa } \\
\text { Pancana }\end{array}$ \\
\hline 1. & abu & afu & katowo \\
\hline 2. & air & te'e & oe \\
\hline 3. & akar & akka & pahaka \\
\hline 4. & aku & iyaku & inodi \\
\hline 5. & alir (meng) & fulu & jala \\
\hline
\end{tabular}

Berdasarkan distribusi leksikon kedua bahasa di atas, terdapat 146 perbedaan leksikon yang tidal kognat.

\subsubsection{Distribusi Leksikon Bahasa Wakatobi Dialek Tomia : Bahasa Pancana}

Berdasarkan distribusi leksikon kedua bahasa di atas yang datanya ada pada Tabel 3 sebelumnya terdapat 144 perbedaan leksikon yang tidak kognat.

\subsubsection{Distribusi Leksikon Bahasa Pancana : Bahasa Kioko}

Di bawah ini akan disajikan sebagian contoh data leksikon yang berbeda antara bahasa Pancana dengan bahasa Kioko.

Tabel 5

Data Leksikon Antara Bahasa Pancana dan Bahasa Kioko

\begin{tabular}{|l|l|l|l|}
\hline No. & Gloss & $\begin{array}{l}\text { Bahasa } \\
\text { Pancana }\end{array}$ & $\begin{array}{l}\text { Bahasa } \\
\text { Kioko }\end{array}$ \\
\hline 1. & abu & katowo & abu \\
\hline 2. & akar & pahaka & kahaa \\
\hline 3. & alir (meng) & jala & nomengalir \\
\hline 4. & anak & ana'i & kaindai \\
\hline 5. & anjing & da'u & mantoa \\
\hline
\end{tabular}

Berdasarkan distribusi leksikon kedua bahasa di atas, terdapat 85 perbedaan leksikon yang tidak kognat.

\subsubsection{Distribusi Leksikon Bahasa} Wakatobi Dialek Tomia : Bahasa Kioko

Di bawah ini akan disajikkan sebagian contoh data leksikon yang berbeda antara bahasa Wakatobi dialek Tomia dengan bahasa Kioko.

Tabel 6

Data Leksikon Antara Bahasa Wakatobi Dialek Tomia dan Bahasa Kioko

\begin{tabular}{|l|l|l|l|}
\hline No. & Gloss & $\begin{array}{l}\text { Bahasa } \\
\text { Wakatobi } \\
\text { Dialek } \\
\text { Tomia }\end{array}$ & $\begin{array}{l}\text { Bahasa } \\
\text { Kioko }\end{array}$ \\
\hline 1. & abu & gopo & abu \\
\hline 2. & air & te;e & oe \\
\hline 3. & akar & akka & kahaa \\
\hline 4. & aku & yaku & inoi \\
\hline 5. & alir (meng) & fulu & nomengalir \\
\hline
\end{tabular}

Berdasarkan distribusi leksikon kedua bahasa di atas, terdapat 142 perbedaan leksikon yang tidak kognat.

\subsubsection{Distribusi Leksikon Bahasa Wakatobi Dialek Tomia : Bahasa Cia-Cia}

Di bawah ini akan disajikkan sebagian contoh data leksikon yang berbeda antara bahasa Wakatobi dialek Tomia dengan bahasa CiaCia.

Tabel 7

Data Leksikon Antara Bahasa Wakatobi Dialek Tomia dan Bahasa Cia-Cia

\begin{tabular}{|l|l|l|l|}
\hline No. & Gloss & $\begin{array}{l}\text { Bahasa } \\
\text { Wakatobi } \\
\text { Dialek }\end{array}$ & $\begin{array}{l}\text { Bahasa } \\
\text { Cia-Cia }\end{array}$ \\
\hline
\end{tabular}




\begin{tabular}{|l|l|l|l|}
\hline & & Tomia & \\
\hline 1. & abu & gopo & awu \\
\hline 2. & akar & akka & purasa \\
\hline 3. & aku & yaku & inda'u \\
\hline 4. & alir (meng) & fulu & wa'a \\
\hline 5. & anak & ana & ungkaka \\
\hline
\end{tabular}

Berdasarkan distribusi leksikon kedua bahasa di atas, terdapat 149 perbedaan leksikon yang tidak kognat.

\subsubsection{Distribusi Leksikon Bahasa Cia-Cia dan Bahasa Kioko}

Di bawah ini akan disajikkan sebagian contoh data leksikon yang berbeda antara bahasa CiaCia dengan bahasa Kioko.

Tabel 8

Data Leksikon Antara Bahasa Kioko dan Bahasa Cia-Cia

\begin{tabular}{|l|l|l|l|}
\hline No. & Gloss & $\begin{array}{l}\text { Bahasa } \\
\text { Kioko }\end{array}$ & $\begin{array}{l}\text { Bahasa } \\
\text { Cia-Cia }\end{array}$ \\
\hline 1. & akar & purasa & kahaa \\
\hline 2. & aku & inda'u & inoi \\
\hline 3. & alir (meng) & wa'a & nomengalir \\
\hline 4. & anak & ungkaka & kaindai \\
\hline 5. & angin & ngoi & kawae \\
\hline
\end{tabular}

Berdasarkan distribusi leksikon kedua bahasa di atas, terdapat 149 perbedaan leksikon yang tidak kognat.

Berdasarkan distribusi leksikon kedua bahasa di atas, terdapat 130 perbedaan leksikon yang tidak kognat

\subsubsection{Distribusi Leksikon Bahasa Wakatobi Dialek Tomia dan Bahasa Kioko}

Berdasarkan distribusi leksikon kedua bahasa di atas yang datanya ada pada tabel 2)-c) sebelumnya terdapat 142 perbedaan leksikon yang tidak kognat.

\subsubsection{Distribusi Leksikon Bahasa Cia-Cia dan Bahasa Kioko}

Berdasarkan distribusi leksikon kedua bahasa di atas yang datanya ada pada Tabel 6 sebelumnya terdapat 130 perbedaan leksikon yang tidak kognat.

\subsubsection{Distribusi Leksikon Bahasa Kioko dan Bahasa Tolaki}

Di bawah ini akan disajikkan sebagian contoh data leksikon yang berbeda antara bahasa Kioko dengan bahasa Tolaki.

Tabel 9

Data Leksikon Antara Bahasa Kioko dan Bahasa Tolaki

\begin{tabular}{|l|l|l|l|}
\hline No. & Gloss & $\begin{array}{l}\text { Bahasa } \\
\text { Kioko }\end{array}$ & $\begin{array}{l}\text { Bahasa } \\
\text { Tolaki }\end{array}$ \\
\hline 1. & alir (meng) & nomengalir & tetewa \\
\hline 2. & anak & kaindai & ana \\
\hline 3. & angin & kawae & opua \\
\hline 4. & anjing & mantoa & o'dau \\
\hline 5. & apa & fae & o'hawo \\
\hline
\end{tabular}

Berdasarkan distribusi leksikon kedua bahasa di atas, terdapat 149 perbedaan leksikon yang tidak kognat .

\subsubsection{Distribusi Leksikon Bahasa Tolaki dan Bahasa Cia-Cia}

Di bawah ini akan disajikan sebagian contoh data leksikon yang berbeda antara bahasa Tolaki dengan bahasa Cia-Cia.

Tabel 10

Data Leksikon Antara Bahasa Tolaki dan Bahasa Cia-Cia

\begin{tabular}{|l|l|l|l|}
\hline No. & Gloss & $\begin{array}{l}\text { Bahasa } \\
\text { Tolaki }\end{array}$ & $\begin{array}{l}\text { Bahasa } \\
\text { Cia-Cia }\end{array}$ \\
\hline 1. & akar & haka & purasa \\
\hline 2. & alir (meng) & tetewa & wa'a \\
\hline 3. & anak & ana & ungkaka \\
\hline 4. & angin & opua & ngoi \\
\hline 5. & anjing & o'dau & au \\
\hline
\end{tabular}

Berdasarkan distribusi leksikon kedua bahasa di atas, terdapat 180 perbedaan leksikon yang tidak kognat.

\subsection{Hasil Perhitungan Dialektometri Segitiga}

Berdasarkan gambar dilalektometri segitiga di atas, maka pasangan bahasa yang menjadi titik pengamatan dapat dilihat pada tabel 11 berikut.

Tabel 11

Data Titik Bahasa dan Jenis Bahasa

\begin{tabular}{|l|l|l|}
\hline No. & $\begin{array}{l}\text { Titik } \\
\text { pengamatan }\end{array}$ & Jenis bahasa \\
\hline 1. & $1-2$ & $\begin{array}{l}\text { Wakatobi dialek } \\
\text { Kaledupa - Wakatobi } \\
\text { dialek Tomia }\end{array}$ \\
\hline 2. & $2-4$ & $\begin{array}{l}\text { Wakatobi dialek Tomia }- \\
\text { Pancana }\end{array}$ \\
\hline
\end{tabular}




\begin{tabular}{|l|l|l|}
\hline 3. & $4-1$ & $\begin{array}{l}\text { Pancana - Wakatobi } \\
\text { dialek Kaledupa }\end{array}$ \\
\hline 4. & $4-5$ & Pancana - Kioko \\
\hline 5. & $5-2$ & $\begin{array}{l}\text { Kioko - Wakatobi dialek } \\
\text { Tomia }\end{array}$ \\
\hline 6. & $2-3$ & $\begin{array}{l}\text { Wakatobi dialek Tomia - } \\
\text { Cia-Cia }\end{array}$ \\
\hline 7. & $3-5$ & Cia-Cia - Kioko \\
\hline 8. & $5-6$ & Kioko - Tolaki \\
\hline 9. & $6-3$ & Tolaki - Cia-Cia \\
\hline
\end{tabular}

Data perbedaan leksikal diperoleh melalui rumus dialektometri Seguy - Guiter, yakni:

$$
\frac{s}{n} \times 100 \%=d
$$

$\mathrm{s}=$ jumlah beda dengan titik pengamatan Lain

$\mathrm{n}=$ jumlah peta yang diperbandingkan

$\mathrm{d}=$ Jarak kosakata dalam \%

hasil yang diperoleh dari perhitungan dialektometri ini akan digunakan untuk menentukan hubungan antar-DP dengan kriteria sebagai berikut:

$81 \%$ ke atas : dianggap perbedaan bahasa

$51 \%-80 \%$ : dianggap perbedaan dialek

$31 \%-50 \%$ : dianggap perbedaan subdialek

$21 \%$ - $30 \%$ : dianggap perbedaan wicara

Dibawah $20 \%$ : dianggap tidak ada perbedaan.

Tabel 12

Jumlah Perbedaan Leksikal pada Enam Titik Pengamatan

\begin{tabular}{|l|l|l|}
\hline No. & \multicolumn{1}{|c|}{$\begin{array}{c}\text { DP yang } \\
\text { dibandingkan }\end{array}$} & \multicolumn{1}{|c|}{$\begin{array}{c}\text { Jumlah Beda } \\
\text { Leksikon }\end{array}$} \\
\hline 1 & $1: 2$ & 29 \\
\hline 2 & $2: 4$ & 144 \\
\hline 3 & $4: 1$ & 146 \\
\hline 4 & $4: 5$ & 85 \\
\hline 5 & $5: 2$ & 142 \\
\hline 6 & $2: 3$ & 149 \\
\hline 7 & $3: 5$ & 130 \\
\hline 8 & $5: 6$ & 149 \\
\hline 9 & $6: 3$ & 180 \\
\hline
\end{tabular}

Selanjutnya, pada tabel 13 tampak penghitungan dialektometri dan penetapan status dialek geografis bahasa daerah di Sulawesi Tenggara.

\section{Tabel 13}

Tabel Penghitungan Dialektometri

\begin{tabular}{|l|l|l|l|l|}
\hline $\begin{array}{l}\mathrm{N} \\
\mathrm{o}\end{array}$ & $\begin{array}{l}\text { DP } \\
\text { yang } \\
\text { diband } \\
\text { ingkan }\end{array}$ & $\begin{array}{l}\text { Penghitungn } \\
\text { Dialektometri }\end{array}$ & $\begin{array}{l}\text { Hasil } \\
(\%)\end{array}$ & Status \\
\hline 1 & $1: 2$ & $\frac{29 \times 100}{200}$ & $14,5 \%$ & $\begin{array}{l}\text { Tidak ada } \\
\text { perbedaan }\end{array}$ \\
\hline 2 & $2: 4$ & $\frac{144 \times 100}{200}$ & $72 \%$ & $\begin{array}{l}\text { Perbedaan } \\
\text { dialek }\end{array}$ \\
\hline 3 & $4: 1$ & $\frac{146 \times 100}{200}$ & $73 \%$ & $\begin{array}{l}\text { Perbedaan } \\
\text { dialek }\end{array}$ \\
\hline 4 & $4: 5$ & $\frac{85 \times 100}{200}$ & $42,5 \%$ & $\begin{array}{l}\text { Perbedaan } \\
\text { Subdialek }\end{array}$ \\
\hline 5 & $5: 2$ & $\frac{142 \times 100}{200}$ & $71 \%$ & $\begin{array}{l}\text { Perbedaan } \\
\text { dialek }\end{array}$ \\
\hline 6 & $2: 3$ & $\frac{149 \times 100}{200}$ & $74.5 \%$ & $\begin{array}{l}\text { Perbedaan } \\
\text { dialek }\end{array}$ \\
\hline 7 & $3: 5$ & $\frac{130 \times 100}{200}$ & $65 \%$ & $\begin{array}{l}\text { Perbedaan } \\
\text { dialek }\end{array}$ \\
\hline 8 & $5: 6$ & $\frac{149 \times 100}{200}$ & $74.5 \%$ & $\begin{array}{l}\text { Perbedaan } \\
\text { dialek }\end{array}$ \\
\hline 9 & $6: 3$ & $\frac{180 \times 100}{200}$ & $90 \%$ & $\begin{array}{l}\text { Perbedaan } \\
\text { bahasa }\end{array}$ \\
\hline
\end{tabular}

\section{Simpulan}

Berdasarkan hasil penjabaran pembahasan hasil penelitian di atas, maka dapat disimpulkan bahwa keseluruhan titik pengamatan yang dianalisis dengan menggunakan perhitungan dialektometri Seguy-Guitar masuk pada empat formulasi, yaitu formulasi di bawah $20 \%$ (tidak ada perbedaan bahasa dan dialek), formulasi 31$50 \%$ (adanya perbedaan subdialek), formulasi $51-80 \%$ (perbedaan dialek), dan formulasi 81 ke atas (perbedaan bahasa). Hal ini menunjukkan bahwa ada perbedaan antara titik-titik pengamatan yang diteliti, ke semua bahasa tersebut ada yang merupakan satu bahasa, satu bahasa berbeda dialek, satu dialek berbeda subdialek, dan perbedaan bahasa.

Formulasi di bawah 20\% (tidak ada perbedaan bahasa dan dialek, yakni antara bahasa Wakatobi dialek Kaledupa dan dialek Tomia), formulasi 31-50 \% (adanya perbedaan subdilek, yaitu antara bahasa Pancana dan bahasa Kioko), formulasi $51-80 \%$ (perbedaan dialek, yakni antara bahasa Wakatobi dialek 
Tomia dan bahasa Pancana; bahasa Pancana dan bahasa Wakatobi dialek Kaledupa; bahasa Kioko dan bahasa Wakatobi dialek Tomia; bahasa Wakatobi dialek Tomia dan bahasa Cia-Cia; bahasa Cia-Cia dan bahasa Kioko; bahasa Kioko dan Bahasa Tolaki), dan formulasi 81 keatas (perbedaan bahasa, yakni antara bahasa Tolaki dan bahasa Cia-Cia).

\section{Daftar Pustaka}

Ayatrohaedi. 1979. Dialektologi, Sebuah Pengantar. Jakarta: Pusat Pembinaan dan Pengembangan Bahasa. 1985. Bahasa Sunda di Daerah Cirebon: Sebuah Kajian Lokabasa. Jakarta: Balai Pustaka.

Bust, R.A. 1977. "The Proto-Austronesian Pronoun and Austronesian Subgrouping, A Prelimeminary Report". Working Paper In Linguistics. Hawaii, 9(2): 1-15.

Esser, S. J. 1983. Languages. Atlas van Tropisch Nederland, sheet 9, 9b. Amsterdam: Koninklijk Nederlandsch Aardrijkskundig Genootschap.

Fernandez, Inyo Yos. 1993. Dialektologi Sinkronis dan Diakronis Sebuah Pengantar. Yogyakarta: UGM.

Guiter, Hendri. 1973. "Atlas et Frontiere Linguistique". Les Dialectes Romas de France No. 30. Paris. Centre National de la Recherche Scientefique.

Kridalaksana, Harimurti. 2008. Kamus Linguistik. Jakarta: PT. Gramedia Pustaka Utama.

Lauder, Multamia R. M. T. 2001. Pemetaan dan Distribusi Bahasa-Bahasa di Tanggerang. Jakarta: Pustaka Bahasa Jakarta.

Marafad, La Ode Sidu. 2001. "Pengelompokkan Genetis Bahasabahasa di Sulawesi Tenggara". Laporan Penelitian. Jakarta: Pusat Pengembangan dan Pembinaan Bahasa, Departemen Pendidikan Indonesia.

Nothofer, Bernd. 1980. Dialectgeographische Untersuchengen du in West-Java und im Westichen Zentral-Java. Dua Jilid. Wiesbaden: Horrossowitz.
Wacana, Gitit I. P. 2013. "Relasi Kekerabatan Bahasa-bahasa di Kabupaten Poso". Jurnal Kependidikan. Vol. 6, No. 1, Juli.

Yatim, Nurdin dan Hamzah Machmoed. (2007). "Distribusi Bahasa Duri dan Bahasa Toraja: Suatu Analisis Geografis Dialek". Jurnal Ilmiah Masyarakat Linguistik Indonesia. Tahun ke 25, No. 1, Februari.

Alwi, Hasan et al. (2008). Kamus Besar Bahasa Indonesia Pusat Bahasa. Jakarta: PT Gramedia Pustaka Utama.

Anderson, L. W \& David R. Krathwohl. (2010). Terjemahan. Kerangka Landasan Untuk Pembelajaran, Pengajaran, dan Asesmen. Revisi Taksonomi Bloom. Yogyakarta: Pustaka Pelajar.

Susiati, S. (2020). Semantik: Teori Semantik, Relasi Makna, Marked, Dan Unmarked.

Jannah, Almaidatul, Wahyu Widayati, Kusmiyati. (2017). "Bentuk dan Makna Kata Makian di Terminal Purabaya Surabaya dalam Kajian Sosiolinguistik". Jurnal Ilmiah Fonema. Vol. 4, No. 2.

Susiati, S. (2020). Fenomena Tuturan Emosi Verbal Bahasa Indonesia Suku Bajo Sampela.

Kisyani. (2004). Bahasa Jawa di Jawa Timur Bagian Utara dan Blambangan. Jakarta: Pusat Bahasa, Departemen Pendidikan Nasional.

Susiati, S. (2020). Kaidah Fonologi Bahasa Indonesia.

Moleong, Lexi. (2007). Metodologi Penelitian Kualitatif. $\quad$ Bandung: Remaja Rosdakarya.

Susiati, S. (2020). Makian Bahasa Wakatobi Dialek Kaledupa.

Sibarani, Robert. (2004). Antropolinguistik: Antropologi Linguistik, Linguistik Antropologi. Medan: Poda. 
Susiati, S. (2020). Fenomena Tuturan Emosi Verbal Bahasa Indonesia Suku Bajo Sampela.

Sumarsono. (2007). Sosiolinguistik. Yogyakarta: Sabda dan Pustaka Pelajar.

Susiati. (2018). "Hominimi Bahasa Kepulauan Tukang Besi Dialek Kaledupa”. Jurnal Totobuang. Vol. 6, No. 1.

Wijana, I Dewa Putu dan Muhammad Rohmadi. (2006). Sosiolinguistik: Kajian Teori dan Analisis. Yogyakarta: Pustaka Pelajar.

Susiati, S. (2020). Kaidah Fonologi Bahasa Indonesia.

Winarsih, Tri. (2010). "Pisuhan dalam 'Basa Suroboyoan' Kajian Sosiolinguistik”. Tesis. Surakarta: UNS.

Susiati, S. (2020). Nilai Budaya Suku Bajo Sampela Dalam Film The Mirror Never Lies Karya Kamila Andini.

Abidin, Zainal. 2007. Analisis Eksistensial, Sebuah Pendekatan Alternatif untuk Psikologi dan Psikiatri. Jakarta: PT Raja Grafindo.

Susiati, S. (2020). Eksistensi Manusia Dalam Film" Aisyah Biarkan Kami Bersaudara" Karya Herwin Novianto.

Bagus, Lorens. 2005. Kamus Filsafat. Jakarta: Gramedia Pustaka Utama.

Susiati, S. Bahan Ajar: Psikolinguistik.

Dila, Putri Andini Kusumawardani. 2017. "Gambaran Eksistensi Tokoh Sandra dalam Film Deux Jours Une Nuit Karya Jean-Plerre Dardenne dan Luc Dardenne: Kajian Psikologi Eksistensial". Thesis. Universitas Brawijaya.

Susiati, S. (2020). Kaidah Fonologi Bahasa Indonesia.

Djojosuroto, Kinayati. 2007. Filsafat Bahasa. Yogyakarta: Pustaka Book.

Susiati, S. (2020). Morfologi Kelas Kata Dalam Bahasa Indonesia.

Klarer, Mario. 1998. An Introduction to Literary Studies. London: Routledge.
Susiati, S., \& Iye, R. (2018). Kajian Geografi Bahasa dan Dialek di Sulawesi Tenggara: Analisis Dialektometri. Gramatika: Jurnal Ilmiah Kebahasaan dan Kesastraan, 6(2), 137-151.

Iye, R., Susiati, S., \& Karim, K. (2020). Citra Perempuan dalam Iklan Sabun Shinzui. Sang Pencerah: Jurnal Ilmiah Universitas Muhammadiyah Buton, 6(1), 1-7.

Moleong, Lexi. 2007. Metodologi Penelitian Kualitatif. Bandung: Remaja Rosdakarya.

Susiati, S., Iye, R., \& Suherman, L. O. A. (2019). Hot Potatoes Multimedia Applications in Evaluation of Indonesian Learning In SMP Students in Buru District. ELS Journal on Interdisciplinary Studies in Humanities, 2(4), 556-570.

Kartono, Kartini. (1980). Pengantar Metodologi Research Sosial. Bandung: Alumni.

Susiati, S. (2020). Pengaplikasian Multimedia Hot Potatoes Dalam Evaluasi Pembelajaran Bahasa Indonesia Pada Siswa SMP Negeri 9 Buru.

.Amanto, B. S., Umanailo, M. C. B., Wulandari, R. S., Taufik, T., \& Susiati, S. (2019). Local Consumption Diversification. Int. J. Sci. Technol. Res, 8(8), 1865-1869.

Susiati, S. (2020). Kesantunan Imperatif Bahasa Melayu Ambon.

Harziko, H., Said, I. M., \& Darwis, K. (2018). FOLLOW THE EVENTS IN THE INDONESIAN LANGUAGE EXPRESSIVE SAID TRANSACTION IN THE TRADITIONAL MARKET TOWN OF BAUBAU. JURNAL ILMU BUDAYA, 6(1).

Susiati, S. (2020, June 18). Eksistensi Manusia Dalam Film "Aisyah Biarkan Kami Bersaudara" Karya Herwin Novianto. https://doi.org/10.31813/gramatika/7.1.2 019.173.50--63

Iye, R., \& Susiati, S. (2018). NILAI EDUKATIF DALAM NOVEL SEBAIT CINTA DI BAWAH LANGIT KAIRO KARYA MAHMUD JAUHARI ALI 
(Educative Values in Sebait Cinta di Bawah Langit Kairo by Mahmud Jauhari Ali). Sirok Bastra, 6(2), 185-191.

Susiati, S. (2018). Homonim bahasa kepulauan tukang besi dialek kaledupa di kabupaten wakatobi [the homonymon of tukang besi island languange in kaledupa dialect at wakatobi regency]. Totobuang, 6 (1), 109, 123.

Nurhayati, N., \& Said, I. (2019). Emosi Verbal Suku Bajo Sampela. Sosial Budaya, 16(2), 114-126.

Susiati, S., \& Iye, R. (2018). Kajian Geografi Bahasa dan Dialek di Sulawesi Tenggara: Analisis Dialektometri. Gramatika: Jurnal Ilmiah Kebahasaan dan Kesastraan, 6(2), 137-151.

Andini, K. NILAI BUDAYA SUKU BAJO SAMPELA DALAM FILM THE MIRROR NEVER LIES KARYA KAMILA ANDINI.

Susiati, S. (2020). Nilai Budaya Suku Bajo Sampela Dalam Film The Mirror Never Lies Karya Kamila Andini.

Said, I. EMOSI VERBAL SUKU BAJO SAMPELA.

Susiati, S. (2020). Metode Pembelajaran Bahasa Indonesia: Sosiodrama.

Tahir, S. Z. B., Atmowardoyo, H., \& Dollah, S. (2018). BELAJAR BERBICARA MULTIBAHASA UNTUK SANTRI PESANTREN. Yogyakarta, Deepublish.

Susiati, S. (2020). Morfologi Kelas Kata Dalam Bahasa Indonesia.

Susiati, S. (2020). Fenomena Tuturan Emosi Verbal Bahasa Indonesia Suku Bajo Sampela.

Tenriawali, A. Y. (2018). Representasi korban kekerasan dalam teks berita daring tribun timur: analisis wacana kritis [the representation victims of violence in tribun timur online news text: critical discourse analysis]. TOTOBUANG, 6 (1), $1,15$.

Susiati, S., \& Iye, R. (2018). Kajian Geografi Bahasa dan Dialek di Sulawesi Tenggara: Analisis Dialektometri. Gramatika: Jurnal Ilmiah Kebahasaan dan Kesastraan. 6 (2), 137-151.
Djamudi, N. L., Nurlaela, M., Nazar, A., Nuryadin, C., Musywirah, I., \& Sari, H. (2019, October). Alternative social environment policy through educational values in Kafi'a's customary speech to the kaledupa community of Wakatobi Island, Indonesia. In IOP Conference Series: Earth and Environmental Science (Vol. 343, No. 1, p. 012118). IOP Publishing.

Susiati, S. (2020). Gaya Bahasa Secara Umum Dan Gaya Bahasa Pembungkus Pikiran: Stilistika.

Susiati, Y. T. Risman Iye. A. Kesantunan Imperatif Bahasa Indonesia Suku Bajo Sampela: Balai Pembinaan dan Pengembangan Bahasa. 2018. Kongres Bahasa Indonesia (No. 12, pp. 1-6). Report.

Susiati, S. (2020). Kesantunan Imperatif Bahasa Melayu Ambon.

Mufidah, N., \& Tahir, S. Z. B. (2018). Empowering E-Learning As An Interactive Teaching For Arabic Learners. Lisanudhad, 5(2), 57-72.

Susiati, S. (2020). Gaya Bahasa Secara Umum Dan Gaya Bahasa Pembungkus Pikiran: Stilistika.

Yusdianti, A. (2020). THE REPRESENTATION VICTIMS OF VIOLENCE IN TRIBUN TIMUR ONLINE NEWS TEXT: CRITICAL DISCOURSE ANALYSIS.

Susiati, S. (2020). Tuturan Kesantunan Imperatif Bahasa Indonesia Suku Bajo Sampela.

Nacikit, J.

PENTINGNYA

MELESTARIKAN

BAHASA

DAERAH.

Susiati, S. (2020). Wujud Morfologi Bahasa Indonesia.

Taufik, T. (2019). Strategi AMBT untuk Meningkatkan Kemampuan Membaca Pemahaman Interpretatif Siswa Kelas IV SD Negeri 3 Namlea Kabupaten Buru. Sang Pencerah: Jurnal Ilmiah Universitas Muhammadiyah Buton, 5(2), 53-62.

Susiati, S. (2020). Morfologi Kelas Kata Dalam Bahasa Indonesia. 
Susiati, S. (2020). PENTINGNYA MELESTARIKAN BAHASA DAERAH.

Susiati, S. (2020). Rekontruksi Internal Bahasa Bugis dan Bahasa Makassar: Linguistik Komparatif.

Susiati, S. (2020). Embrio Nasionalisme Dalam Bahasa dan Sastra.

Leja, W. NILAI PEMBENTUK KARAKTER MASYARAKAT WAKATOBI MELALUI KABHANTI WA LEJA.

Susiati, S. (2020). Teori dan Aliran Linguistik: Tata Bahasa Generatif.

Susiati, S. (2020). Semantik: Teori Semantik, Relasi Makna, Marked, Dan Unmarked.

Susiati, S. (2020). Metode Pembelajaran Bahasa Indonesia: Sosiodrama.

Susiati, S. PERWUJUDAN SIMILE OLEH MERARI SIREGAR DALAM NOVEL AZAB DAN SENGSARA.

Susiati, S. (2020, June 21). Bahan Ajar: Psikolinguistik. https://doi.org/10.31219/osf.io/9hveb

Susiati, S. (2020). The Concept Of Togetherness In The Films" Aisyah Biarkan Kami Bersaudara" By Herwin Novianto.

Susiati, S. (2020). Konsep Pertentangan Dalam Film" Aisyah Biarkan Kami Bersaudara" Karya Herwin Novianto.

Susiati, S. (2020). Konsep Kebersamaan Dalam Film" Aisyah Biarkan Kami Bersaudara" Karya Herwin Novianto. 